\title{
Ameliorative Effect of Bacillus sp. MN-54 and Organic Amendments Combination on Maize Plants Growth and Physiology Under Chromium Toxicity
}

\author{
Muhammad Abubakar ${ }^{1}$, Muhammad Naveed ${ }^{1}$, Zulfiqar Ahmad ${ }^{1}$, Sardar Alam Cheema ${ }^{1}$, Ali Sultan Khan ${ }^{2}$, \\ Ha Young Park ${ }^{2} \&$ Chan Ho Kwon ${ }^{2}$ \\ ${ }^{1}$ Institute of Soil \& Environmental Science, University of Agriculture, Faisalabad, Pakistan \\ ${ }^{2}$ Department of Animal Science, Kyungpook National University, South Korea \\ Correspondence: Ali Sultan Khan, Department of Animal Science, Kyungpook National University, South Korea. \\ E-mail: ali.sultan.khan.95@knu.ac.kr
}

Received: September 17, 2020

Accepted: October 28, 2020

Online Published: November 15, 2020

doi:10.5539/jas.v12n12p39

URL: https://doi.org/10.5539/jas.v12n12p39

\begin{abstract}
Inoculation of bacteria increase the growth of maize by facilitating the nutrients uptake and improving the immunity of plants and ability against pathogens, harmful substances such as heavy metals and other diseases. Likewise, organic amendments also increase the growth of plants by providing ample amount of readily available nutrients and improving soil physical conditions and ameliorating heavy metals toxicity. In this study, a pot experiment was conducted to evaluate the interactive effect of bacteria and organic amendments on $\mathrm{Cr}$ uptake and growth of maize irrigated with tannery effluent. Biochar and processed animal manure were applied at the rate of $1 \%(\mathrm{w} / \mathrm{w})$. The experiment was conducted as Completely Randomized Design (CRD) with three replications. During the experiment various growth, physiological and biochemical parameters were measured by using standard procedures. Combination of Bacillus sp. MN-54 and low pH animal manure increased the plant height by $72 \%$, chlorophyll content by $56 \%$, water use efficiency by $68 \%$, electrolyte leakage decreased by $51 \%$, transpiration rate increased by $45 \%$, RWC $57 \%$, stomatal conductance $62 \%$, photosynthetic rate $57 \%$ whereas $\mathrm{Cr}$ decreased the shoot growth by $45 \%$ over their control treatment. Overall the bacterial species evaluated in this study along with biochar and animal manure imparted heavy metal tolerance to maize plants evidenced by improved growth and physiology.
\end{abstract}

Keywords: maize, chromium toxicity, Bacillus sp.

\section{Introduction}

Many industries worldwide drain their wastewater into the sewerage system or directly into the freshwater bodies especially rivers, without required treatment (Zhang, Liu, \& Wang, 2010). Consequently, there is severe negative ecological impact mainly on irrigation water quality, recreation, soil properties and most importantly on human health (Shen, Li, Wang, Chen, \& Chua, 2002). According to Corcoran (2010), about $90 \%$ of the wastewater does not receive any kind of treatment, due to non-enforcement of environmental quality standards and expensive water treatment process. Among the other industries, leather industry is the most polluting and designated "red category" due to high concentration of organic matter, suspended particles, dissolved particle, salts mainly sodium chloride and chromium sulphates being received by the water channels (Haydar \& Aziz, 2009; Reddy \& Behera, 2006; Syed et al., 2010). Leather tanning process uses water and chemicals at maximum amount and for $1 \mathrm{~kg}$ leather processing about 50-150 liters of water and about 130 different types of chemicals ranging from acids, pigments, sulfonated oils, anti-fungal agents, salts, natural and synthetic tanning agents are used. Leather industry is mainly responsible for high concentration of Chromium $(\mathrm{Cr})$ salt and other organic constituents which are hazardous for environment (Saxena, Chandra, \& Bharagava, 2016). Chromium is most abundant heavy metal found in agricultural soils due to the excessive use in various industries (Hamelink et al., 1994) and non-essential nutrient for the plants. In fact, chromium is toxic for plants as it causes hinderance of photosynthetic and respiratory pathways of the plant, leading to plant death (Shanker, Cervantes, Loza-Tavera, \& Avudainayagam, 2005). Later on, it becomes part of the food chain if the plants are consumed by the animals or humans (Staniek, Kostrzewska-Poczekaj, Arndt, Szyfter, \& Krejpcio, 2010). 
Plant growth promoting rhizobacteria (PGPR) are also helpful for promotion of plant growth when PGPR lessens the deleterious effects of toxic nutrients under unfavorable conditions, to improve efficiency of phytoremediation of contaminated water bodies (Liu, Wang, Zhao, \& Yang, 2012). Many studies showed that Chromium reducing microorganisms present an economic, safe and environmental friendly option for reduction of $\mathrm{Cr}$ (VI) to $\mathrm{Cr}$ (III) as microbes have the ability for bio reduction (Camargo, Okeke, Bento, \& Frankenberger, 2003; Chrysochoou, Zhang, \& Amador, 2013; Raspor et al., 2000; Srivastava \& Thakur, 2006; X. Zhang et al., 2013) or reduction through biochar (Agrafioti, Kalderis, \& Diamadopoulos, 2014; Choppala, Bolan, Megharaj, Chen, \& Naidu, 2012; Mohan, Rajput, Singh, Steele, \& Pittman Jr, 2011).

Biochar is very attractive organic amendment for the treatment of contaminants and helps for reduced uptake of heavy metals by the plants. Biochar consist of compounds which are stable and resistant to microbial degradation (Lehmann et al., 2002), have low bulk density (Masulili, Utomo, \& Syechfani, 2010) and increase nutrient availability (Jeffery, Verheijen, van der Velde, \& Bastos, 2011).

However, no study has focused on the synergistic effects of bacterial inoculants and biochar on Cr uptake, speciation, fractionation and growth of maize plants.

So, the aim of this study was to evaluate the effect of combined use of biochar, bacterial inoculants (Bacillus sp. $\mathrm{MN}-54$ ) with low and normal $\mathrm{pH}$ animal manure on the treatment of tannery effluent water used for irrigation. The specific objective of this study was to investigate the ameliorative effect of Bacillus sp. MN-54, biochar and animal manure separately and in combination, both on the growth and physiology of maize plants irrigated by tannery effluents.

\section{Material and Methods}

\subsection{Contaminated Water Collection}

Polluted water to be used for irrigation was collected from Kasur, Pakistan the area full of tannery industry and analyzed for contamination parameters, i.e., Biological oxygen demand, Chemical oxygen demand, sulphates, chlorides, oil and grease and heavy metals especially Chromium (EPA, 1974).

\subsection{Preparation of Biochar}

Biochar was prepared by thermal degradation of organic substances anaerobically (Pyrolysis) at $250-1000{ }^{\circ} \mathrm{C}$ and produced into three components i.e. bio oil, syngas and biochar (Kumar et al., 2013).

\subsection{Inoculant Preparation}

Bacterial strain Bacillus sp. MN-54 was stored at $-75^{\circ} \mathrm{C}$ in nutrient broth amended with $10 \%$ glycerol and were regularly cultured on tenth-strength tryptic soy agar (10\% TSA). Selected strains were prepared in $10 \%$ tryptic soy broth. The culture was inoculated with bacterial loop full and incubated at $28 \pm 1{ }^{\circ} \mathrm{C}$ for $72 \mathrm{~h}$ at $100 \mathrm{rev} / \mathrm{min}$ (Firstek Scientific, Tokyo, Japan). Optical density was adjusted at 0.5 measured at $600 \mathrm{~nm}$ using spectrophotometer to obtain a uniform population of bacteria $\left(10^{8}-10^{9} \mathrm{cfu} \mathrm{ml}^{-1}\right)$ in the broth before application (Akinrinola et al., 2018).

\subsection{Greenhouse Pot Tests}

Pot trail was conducted at the research area of Institute of Soil and Environmental Sciences, University of Agriculture, Faisalabad to assess the interactive effects of Bacillus sp. MN-54 with organic amendments on the chromium uptake, growth and development of maize irrigated with tannery effluents. Soil was grinded and sieved at $2 \mathrm{~mm}$ and $8 \mathrm{~kg}$ soil was filled in each pot. Bacterial inoculant was applied at the rated of $20 \mathrm{ml} / \mathrm{pot}$. Biochar and animal manure were applied at the rate of $1 \%(w / w)$. Maize seeds were sown in each pot and after germination two plants/pot were maintained. Tannery effluent water was applied at $50 \%$ dilution for irrigation. 
Table 1. Treatments plan followed for the experiment

\begin{tabular}{ll}
\hline Treatments & Treatment Explanation \\
\hline T0 & Control \\
T1 & Bacillus sp. MN-54 \\
T2 & Biochar \\
T3 & Low pH animal manure \\
T4 & Normal pH animal manure \\
T5 & Bacillus sp. MN-54 + Biochar \\
T6 & Bacillus sp. MN-54 + Low pH animal manure \\
T7 & Bacillus sp. MN-54 + Normal pH animal manure \\
\hline
\end{tabular}

\subsection{Data Collection}

Data for different parameters was recorded by adopting standard procedures throughout the experimental duration.

\subsubsection{Agronomic Parameters}

\section{(1) Shoot Fresh and Dry Weight (g)}

The shoot fresh weight was measured after the harvesting of crop. Shoot dry weight was measured after the drying of samples. The samples were air dry and put in oven at $65^{\circ} \mathrm{C}$ and when samples were fully dry then the weight was measured with the help of electrical balance (Chyo MJ-3000).

(2) Length of Shoot (cm)

Shoot length of the plants was measured at the time of harvesting. Shoot length was measured with the help of meter scale. Shoot length was measured from bottom to top.

(3) Root Fresh and Dry Weight (g)

Root fresh weight was measured after removing the roots from pots. After removing plants from pots roots were air dried for three days and put in oven for drying at the temp $65{ }^{\circ} \mathrm{C}$ for the period of one weak. When samples were fully dried the root, dry weight was measured with electrical balance (Chyo MJ-3000).

\subsubsection{Physiological Parameters}

\section{(4) Infrared Gas Analyzer (IRGA)}

To measure photosynthetic rate, stomatal conductance, transpiration rate and water use efficiency, two fully mature and prolonged leaves being exposed to direct solar radiation were selected for the measurement of these parameters between 1100 and 1300 hours local time on a clear and sunny day using infrared gas analyser (LI-6400 Portable Photosynthesis System, LI-COR, USA). Temperature at the time of measurements varied between $28-32{ }^{\circ} \mathrm{C}, 80 \%$ relative humidity and photon flux density of $1500 \mu \mathrm{mol} \mathrm{m} \mathrm{m}^{-2} \mathrm{~S}^{-1}$ (Ben-Asher, Tsuyuki, Bravdo, \& Sagih, 2006).

\section{(5) Chlorophyll and Relative Water Contents}

Chlorophyll contents were measured using SPAD-502 chlorophyll meter (Konica Mintola Sensing, Inc., Japan). Relative water content was measured by weighing a fresh leaf and putting into water for 48 hours at $4{ }^{\circ} \mathrm{C}$ and again weighing that leaf. The relative water content was calculated with the help of this formula of Mayak, Tirosh, and Glick (2004).

\section{(6) Cell Death Assessment}

$$
\text { Relative water content }(\text { RWC })=\frac{\text { Turgid weight }- \text { Dry weight }}{\text { Fresh weight }- \text { Dry Weight }}
$$

Stress-induced cell death was measured by assessment of electrolyte leakage from plant tissues (Lutts et al., 1995). Leaves were washed for any dust, cut and soaked in $10 \mathrm{ml}$ distilled water for 24 hours. Electrical conductivity (EC1) was noted and samples were autoclaved at $120^{\circ} \mathrm{C}$ electrical conductivity was again measured (EC2). Electrolyte leakage was measured according to following formula:

$$
\text { Electrolyte leakage }(\%)=\frac{\mathrm{EC} 2-\mathrm{EC} 1}{\mathrm{EC} 2} \times 100
$$




\subsubsection{Chemical Parameters}

(7) Plant Analysis

For determination of NPK content in the maize plants, root and shoot samples were digested with $2 \mathrm{ml}$ sulphuric acid and $1 \mathrm{ml}$ hydrogen peroxide (Wolf, 1982).

Nitrogen was measured using Kjeldahl apparatus (Jackson, 1962). Phosphorous was measured by treating $5 \mathrm{ml}$ digested sample with $10 \mathrm{ml}$ Barton reagents $(25 \mathrm{~g}$ ammonium molybdate and $1.25 \mathrm{~g}$ ammonium meta-vanadate. After that, $\mathrm{HNO}_{3}$ was used to make volume of 1 liter. After 30 minutes, absorbance was measured at $410 \mathrm{~nm}$ using spectrophotometer against the standard. Potassium was measured using flame photometer and read against the standards (Emmert, 1932). Double dry digestion method for the assessment of chromium was used (Blincoe, Theisen, \& Stoddard-Gilbert, 1987).

(8) Soil Analysis

AB-DTPA method was used for determination of Cr(VI) in the soil (Soltanpour \& Schwab, 1977). 10g soil was digested with $20 \mathrm{ml}$ AB-DPTA solution for 2 hours on shaker with 180 cycles per minute. Samples were filtered and subjected to atomic absorption spectrophotometer. For total chromium in soil ICARDA manual was followed (Estefan, Sommer, \& Ryan, 2013).

\subsection{Statistical Analysis}

The data was subjected to analysis of variance (ANOVA) using SPSS software version 25. Means were reported at $\mathrm{P}<0.05$ after Tuckey's T-test option of the SPSS software.

\section{Results and Discussion}

\subsection{Water Quality Analysis}

Water quality analysis (Table 2) revealed the difference between important parameters for the irrigation water quality as total dissolved solids (TDS) was 21 times, biological oxygen demand (B.O.D.) was 558 times, total soluble solids (TSS) was 25 times and chromium was around 100 times higher in the tannery effluent water as recommended limit by FAO (2008).

Table 2. Physiochemical Properties of pre-analysis tannery effluent and recommended values for the irrigation

\begin{tabular}{lll}
\hline Parameter & Tannery effluent & Recommended for irrigation by FAO \\
\hline TDS, mg/L & 21300 & 1000 \\
pH & 8.3 & $6.5-8.4$ \\
Dissolved oxygen, mg/L & 2.72 & $>4.0$ \\
B.O.D., mg/L & 4464 & 8.0 \\
Zinc, mg/L & 1.52 & 2.0 \\
Lead, mg/L & 0.18 & 0.1 \\
TSS, mg/L & 1250 & 50 \\
Chromium, mg/L & 10.35 & 0.10 \\
\hline
\end{tabular}

Note. TSS: Total soluble solids, B.O.D: Biological oxygen demand, TDS: Total dissolved solids.

\subsection{Agronomic Parameters}

Results for agronomic parameters (Table 3) elaborated that treatments having Bacillus sp. MN-54 inoculation enhanced the corn growth compared to other treatments. Shoot length was significantly higher for T6, T5, T7 and T3 and least for control, i.e., $64.67 \mathrm{~cm}$ and approximately 1.4 times lesser than treatment with Bacillus sp. MN-54 inoculation and Low pH animal manure (T6). Interestingly, all the treatments enhanced growth of the maize compared to the control. Root length was also significantly higher for T5 followed by T6 and T7 as compared to other treatments. Following the same trend as that for shoot length as root length was least in control and approximately 2 times shorter than treatment bearing Bacillus sp. MN-54 inoculation and Biochar. Shoot fresh weight was also significantly higher for T6 followed by T7 and T5 as compared to other treatments. Similarly, shoot fresh weight was 1.4 times higher for treatment with Bacillus sp. MN-54 inoculation and Low $\mathrm{pH}$ animal manure as compared to control. Shoot dry weight also showed same results as that was significantly higher for T6 followed by T7 and T5 as compared to other treatments and Bacillus sp. MN-54 inoculation and Low $\mathrm{pH}$ animal manure treatment showed 1.8 times more shoot dry weight as that for control. 
Table 3. Effect of Bacillus sp. MN-54 and organic amendments on agronomic parameters of tannery effluent irrigated maize plants plants

\begin{tabular}{lllllllllll}
\hline Parameter & T0 & T1 & T2 & T3 & T4 & T5 & T6 & T7 & SEM & P-value \\
\hline Shoot length, cm & $64.67^{\mathrm{b}}$ & $79.67^{\mathrm{a}}$ & $81.00^{\mathrm{a}}$ & $83.67^{\mathrm{a}}$ & $78.33^{\mathrm{ab}}$ & $87.33^{\mathrm{a}}$ & $89.67^{\mathrm{a}}$ & $83.33^{\mathrm{a}}$ & 1.69 & 0.00 \\
Root length, cm & $4.37^{\mathrm{c}}$ & $6.33^{\mathrm{b}}$ & $5.97^{\mathrm{bc}}$ & $6.33^{\mathrm{b}}$ & $5.93^{\mathrm{c}}$ & $8.60^{\mathrm{a}}$ & $8.47^{\mathrm{a}}$ & $8.18^{\mathrm{a}}$ & 0.31 & 0.00 \\
Shoot fresh weight, g & $63.33^{\mathrm{c}}$ & $75.33^{\mathrm{b}}$ & $76.67^{\mathrm{b}}$ & $75.00^{\mathrm{b}}$ & $73.00^{\mathrm{b}}$ & $87.67^{\mathrm{a}}$ & $90.67^{\mathrm{a}}$ & $89.67^{\mathrm{a}}$ & 1.93 & 0.00 \\
Shoot dry weight, g & $8.30^{\mathrm{c}}$ & $12.89^{\mathrm{b}}$ & $12.74^{\mathrm{b}}$ & $12.72^{\mathrm{b}}$ & $12.41^{\mathrm{b}}$ & $14.90^{\mathrm{a}}$ & $15.41^{\mathrm{a}}$ & $15.24^{\mathrm{a}}$ & 0.46 & 0.00 \\
\hline
\end{tabular}

Note. Means sharing different superscript letters, within row, differ significantly from each other at $\mathrm{P}<0.05$.

\subsection{Physiological Parameters}

Physiological analysis results are presented in Table 4 and revealed that for osmotic potential T6 was significantly higher than other treatments and 1.5 times higher than control. Photosynthetic rate was also significantly higher for T6 and T7 as compared to other treatments and T6 was around 2 times higher than control. Stomatal conductance was also significantly higher for T6 followed by T5 and T7 as for other treatments and around 1.4 times higher for T6 than control. Electrolyte leakage depicting the extent of cell injury was significantly least for T7 followed by T5 and T6. Highest level of cell injury was shown by control as cell damage was 2 times higher in control as for T7. Water use efficiency was also significantly higher for T6, T7 and T5 as compared to other treatments and 3 times higher for T6 as compared to control. Transpiration rate was significantly higher for T7, T6 and T5 as for other treatments and 2 times higher for treatment with Bacillus sp. MN-54 inoculation and normal $\mathrm{pH}$ animal manure (T7) as compared to control. Photosynthetically active radiations (PAR) was also higher for T6, T5 and T7 as compared to other treatments and T6 was around 1.5 times higher than the control. Chlorophyll contents were the highest in T7 and T6 as compared to the chlorophyll contents in the control treatment plants. Relative water content suggesting the physiological consequences of cellular water deficit was also significantly higher for T5, T6 and T7 as that of other treatments.

Table 4. Effect of Bacillus sp. MN-54 and organic amendments on physiological parameters of tannery effluent irrigated maize plants plants

\begin{tabular}{|c|c|c|c|c|c|c|c|c|c|c|}
\hline Parameter & $\mathrm{T} 0$ & $\mathrm{~T} 1$ & $\mathrm{~T} 2$ & $\mathrm{~T} 3$ & $\mathrm{~T} 4$ & T5 & T6 & $\mathrm{T} 7$ & SEM & P-value \\
\hline Osmotic potential, psi & $0.41^{\mathrm{d}}$ & $0.53^{\mathrm{c}}$ & $0.58^{\text {bc }}$ & $0.59^{\mathrm{abc}}$ & $0.56^{\text {bc }}$ & $0.62^{\mathrm{ab}}$ & $0.63^{\mathrm{a}}$ & $0.61^{\mathrm{ab}}$ & 0.01 & 0.00 \\
\hline Photosynthesis rate, $\mu \mathrm{mol} \mathrm{m} \mathrm{m}^{-2} \mathrm{~s}^{-1}$ & $34.87^{\mathrm{c}}$ & $36.80^{\mathrm{b}}$ & $36.97^{\mathrm{b}}$ & $37.17^{\mathrm{b}}$ & $36.7^{\mathrm{b}}$ & $39.37^{\mathrm{a}}$ & $39.67^{\mathrm{a}}$ & $39.57^{\mathrm{a}}$ & 0.34 & 0.00 \\
\hline Stomatal conductance, $\mathrm{mmol} \mathrm{m} \mathrm{m}^{-2} \mathrm{~s}^{-1}$ & $102.33^{\mathrm{c}}$ & $116.67^{\mathrm{b}}$ & $117.33^{\mathrm{b}}$ & $118.67^{\mathrm{b}}$ & $121.33^{\mathrm{b}}$ & $140.33^{\mathrm{a}}$ & $142.00^{\mathrm{a}}$ & $139.33^{\mathrm{a}}$ & 2.89 & 0.00 \\
\hline Electrolyte leakage, $\%$ & 13.27 & $11.20^{\mathrm{b}}$ & $10.87^{\mathrm{bc}}$ & $9.17^{\mathrm{d}}$ & $9.57^{\text {cd }}$ & $7.10^{\mathrm{e}}$ & $7.23^{\mathrm{e}}$ & $6.9^{\mathrm{e}}$ & 0.45 & 0.00 \\
\hline Water use efficiency, $\mu \mathrm{mol} \mathrm{m} \mathrm{m}^{-2} \mathrm{~s}^{-1}$ & $1.37^{\mathrm{c}}$ & $2.40^{\mathrm{b}}$ & $2.41^{\mathrm{b}}$ & $2.57^{\mathrm{b}}$ & $2.51^{b}$ & $3.61^{\mathrm{a}}$ & $4.03^{\mathrm{a}}$ & $3.84^{\mathrm{a}}$ & 0.19 & 0.00 \\
\hline Transpiration rate, $\mathrm{mmol} \mathrm{m} \mathrm{m}^{-2} \mathrm{~s}^{-1}$ & $5.50^{\mathrm{b}}$ & $7.07^{\mathrm{b}}$ & $7.10^{\mathrm{b}}$ & $7.53^{\mathrm{b}}$ & $7.13^{\mathrm{b}}$ & $11.43^{\mathrm{a}}$ & $11.70^{\mathrm{a}}$ & $12.00^{\mathrm{a}}$ & 0.54 & 0.00 \\
\hline $\mathrm{PAR}, \mathrm{W} / \mathrm{m}^{2}$ & $563.00^{\mathrm{c}}$ & $644.67^{b}$ & $633.00^{\mathrm{b}}$ & $656.33^{\mathrm{b}}$ & $644.67^{\mathrm{b}}$ & $853.33^{\mathrm{a}}$ & $855.00^{\mathrm{a}}$ & $849.33^{\mathrm{a}}$ & 23.67 & 0.00 \\
\hline Chlorophyll Content & $22.00^{\mathrm{d}}$ & $24.27^{\text {cd }}$ & $24.67^{\mathrm{cd}}$ & $26.00^{\text {bcd }}$ & $25.5^{\text {bcd }}$ & $32.67^{\mathrm{a}}$ & $31.30^{\mathrm{ab}}$ & $28.00^{\mathrm{abc}}$ & 0.93 & 0.00 \\
\hline Relative water content, $\%$ & $34.33^{\mathrm{d}}$ & $48.67^{\mathrm{bc}}$ & $46.33^{c}$ & $47.67^{\mathrm{c}}$ & $49.33^{\mathrm{bc}}$ & $61.00^{\mathrm{a}}$ & $60.00^{\mathrm{a}}$ & $57.67^{\mathrm{ab}}$ & 1.80 & 0.00 \\
\hline
\end{tabular}

Note. Means sharing different superscript letters, within row, differ significantly from each other at $\mathrm{P}<0.05$.

\subsection{Chemical Parameters}

Chemical analysis results for different parts of the plant is presented in Table 5. All of the treatments having Bacillus sp. MN-54 inoculation enhanced toxicity resistance extent to the maize plants. Combination of Bacillus sp. MN-54 inoculation with biochar, low and normal $\mathrm{pH}$ animal manure significantly performed better for chromium, nitrogen, phosphorous and potassium concentration in the shoots of maize plants as compared to other treatments as well as the control. 
Table 5. Effect of Bacillus sp. MN-54 and organic amendments on biochemical parameters of tannery effluent irrigated maize plants plants

\begin{tabular}{lllllllllll}
\hline Parameter & T0 & T1 & T2 & T3 & T4 & T5 & T6 & T7 & SEM & P-value \\
\hline Chromium in shoots, ppm & $80.00^{\mathrm{a}}$ & $70.00^{\mathrm{bc}}$ & $72.33^{\mathrm{ab}}$ & $62.33^{\mathrm{c}}$ & $70.00^{\mathrm{bc}}$ & $36.00^{\mathrm{e}}$ & $40.00^{\mathrm{de}}$ & $46.00^{\mathrm{d}}$ & 5.59 & 0.00 \\
Nitrogen in shoots, ppm & $0.11^{\mathrm{f}}$ & $0.14^{\mathrm{e}}$ & $0.17^{\mathrm{d}}$ & $0.19^{\mathrm{c}}$ & $0.16^{\mathrm{d}}$ & $0.25^{\mathrm{a}}$ & $0.24^{\mathrm{a}}$ & $0.21^{\mathrm{b}}$ & 0.01 & 0.00 \\
Phosphorous in shoots, ppm & $0.65^{\mathrm{e}}$ & $0.96^{\mathrm{d}}$ & $1.11^{\mathrm{c}}$ & $1.03^{\mathrm{cd}}$ & $0.94^{\mathrm{d}}$ & $1.85^{\mathrm{a}}$ & $1.70^{\mathrm{b}}$ & $1.60^{\mathrm{b}}$ & 0.08 & 0.00 \\
Potassium in shoots, ppm & $2.13^{\mathrm{e}}$ & $2.45^{\mathrm{de}}$ & $3.15^{\mathrm{c}}$ & $3.13^{\mathrm{c}}$ & $2.91^{\mathrm{cd}}$ & $5.80^{\mathrm{a}}$ & $5.30^{\mathrm{b}}$ & $4.91^{\mathrm{b}}$ & 0.27 & 0.00 \\
\hline
\end{tabular}

Note. Means sharing different superscript letters, within row, differ significantly from each other at $\mathrm{P}<0.05$.

\section{Discussion}

\subsection{Irrigation Water Quality Analysis}

The wastewater analysis showed the dangerously high level of chromium, biological oxygen demand that total dissolved solids and affected the growth, physiological and other factors of the maize plants, pertaining to the fact that higher level of chromium can be lethal and toxic for the plants normal functioning (Anjum et al., 2016).

\subsection{Agronomic Parameters}

Biochar imprioves the nutrient retention, water uptake and increased prganic $\mathrm{C}$, macro and micro-nutrients in soil (Sanchez et al., 2009; Larid et al., 2010), thus improving soil fertility and enhanced vegetative growth (Ali et al., 2017). Chromium toxicity had more pronounced impact on root length as compared to shoot length because plants treated with Bacillus sp. MN-54 and low pH animal manure had approximately 29 percent more shoot length and 48 percent more root length as compared to control, which was due to the toxicity by chromium immobility and effect on cellular division. Jun, Ling, and Guanghua (2009) also observed same reduction of root length, total biomass and plant height reduction. Reduction in root growth can be attributed to inhibition of cellular division in roots, collapse of tissue and incapacity for nutrients and water uptake because of direct contact of root hairs with chromium particles making them unable to imbibe water (Mallick, Sinam, Mishra, \& Sinha, 2010). However, the greater reduction in root length was observed might be due to several factors, (Mallick et al., 2010). The root growth defects under exposure to high levels of $\mathrm{Cr}$ can be caused by inhibition of root cell division and/or reduction of cell proliferation in the root zone of growth (Adrees et al., 2015).

Shoot fresh and dry weight also followed same pattern as Bacillus sp. MN-54 and low pH animal manure treated plants had 46 percent more fresh weight and 29 percent more dry weight for shoot as compared to control plants. The results were in confirmation with Park, Choppala, Bolan, Chung, and Chuasavathi (2011) where chicken manure biochar increased root dry mass and shoot dry mass under $1 \%$ biochar application, pertaining to the fact of better nutrient availability and reduced toxicity. This can be due to the fact that $\mathrm{Cr}$ (VI) can be adsorbed on the surface of biochar or reduced to less toxic form of Cr (Liu, Xu, Zeng, Li, \& Gao, 2006; Şahin \& Öztürk, 2005). In addition, biochar improved the soil properties especially macro and micro-nutrient profile and soil organic matter leading to better plant performance as for the toxicity stressed plants (Ali et al., 2015; Novak et al., 2009).

\subsection{Physiological Parameters}

Bacillus sp. MN-54 and low pH animal manure improved physiological attributes in maize under tannery polluted soil. Among the most significantly impacted physiological attributes were electrolyte leakage, Water use efficiency and transpiration rate. Transpiration rate was 43 percent higher; electrolyte leakage was 83 percent lower and WUE was 66 percent higher in Bacillus sp. MN-54 and low pH animal manure treated plants as compared to control. Physiological parameters were influenced due to detrimental effects on photosynthetic machinery like disorganization of chloroplast, inhibition electron transport, photo-damage photosystem II (PSII) and swelling of chloroplast (Kato, Sun, Zhang, \& Sakamoto, 2012). Iron is essential part of chlorophyll as it is main component of protoporphyrin, a precursor of chlorophyll synthesis and chromium toxicity effect $\mathrm{Fe}$ availability (Bera \& Bokaria, 1999). Arshad et al. (2017) showed 75\% reduction in chlorophyll contents by increasing $\mathrm{Cr}$ (VI) stress, same results shown in our study. This inhibition in chlorophyll content may be due to $\mathrm{Cr}$ (VI) competency of with iron for binding with protoporphyrin.

$\mathrm{Cr}$ (VI) reduction by biochar have been reported by many researches (Choppala et al., 2012; Dong, Ma, \& Li, 2011; Shen, Wang, Tzou, Yan, \& Kuan, 2012) and Arshad et al. (2017) observed 26\% Cr (VI) reduction with 1\% biochar and $48 \% \mathrm{Cr}(\mathrm{VI})$ reduction after 3 weeks with $5 \%$ biochar in wheat. Biochar surface contains free or complexed carboxyl, phenolic hydroxyl or alcoholic hydroxyl groups that play a vital role in heavy metals sorption through inner-sphere complex, electrostatic attraction and precipitation (Lu et al., 2012; B. Singh, B. P. Singh, \& 
Cowie, 2010). Certain hydroxyl and carboxylic moieties are present on biochar that cause Cr (VI) reduction because of polycyclic aromatic hydrocarbons donate p-electrons which reduced $\mathrm{Cr}$ (VI) (Wang et al., 2010). Similarly, precipitation and surface complexation are two main mechanisms that are involved in $\mathrm{Cr}$ (III) adsorption on biochar surface (Hsu, Wang, Lin, Sheng, \& Lee, 2009).

\section{Conclusion}

There are several conclusions from this study. First, tannery effluents are one of the main sources of the heavy metals in water streams as well as in the soil pollution and resultantly hinder the normal performance of the plants. This suggests that there is need of different resources to be explored which impart chromium tolerance and resistance to plants ranging from plant growth promoting bacteria to natural resources such as biochar, animal manure or nanoparticles. Secondly, the bacterial species evaluated in this experiment along with other sources such as biochar and animal manure effectively and significantly imparted chromium toxicity tolerance by reduced chromium uptake to maize plants in terms of growth analysis, physiological analysis as well as chemical composition of different plant parts. This concludes that PGPR with combination of conventional amendments have the potential to reduce the effect of heavy metals toxicity to the maize plants. This study is a preliminary study to identify different bacterial strains for heavy metal tolerance in plants and knowledge about mode of action would be beneficial to match different bacterial strains to different plant species, heavy metals in water or soil for their intended use.

\section{Acknowledgements}

This research was supported by Kyungpook National University Development Project Research Fund, 2018.

\section{References}

Adrees, M., Ali, S., Iqbal, M., Aslam, B. S., Siddiqi, Z., Farid, M., ... Rizwan, M. (2015). Mannitol alleviates chromium toxicity in wheat plants in relation to growth, yield, stimulation of anti-oxidative enzymes, oxidative stress and $\mathrm{Cr}$ uptake in sand and soil media. Ecotoxicol Environm Safety, 122, 1-8. https://doi.org/ 10.1016/j.ecoenv.2015.07.003

Agrafioti, E., Kalderis, D., \& Diamadopoulos, E. (2014). Arsenic and chromium removal from water using biochars derived from rice husk, organic solid wastes and sewage sludge. Journal of Environmental Management, 133, 309-314. https://doi.org/10.1016/j.jenvman.2013.12.007

Ali, S., Chaudhary, A., Rizwan, M., Anwar, H. T., Adrees, M., Farid, M., ... Anjum, S. A. (2015). Alleviation of chromium toxicity by glycinebetaine is related to elevated antioxidant enzymes and suppressed chromium uptake and oxidative stress in wheat (Triticum aestivum L.). Environmental Science and Pollution Research, 22(14), 10669-10678. https://doi.org/10.1007/s11356-015-4193-4

Ali, S., Rizwan, M., Qayyum, M. F., Ok, Y. S., Ibrahim, M., Riaz, M., ... Shahzad, A. N. (2017). Biochar soil amendment on alleviation of drought and salt stress in plants: A critical review. Environ Sci Pollut Res Int., 24(14), 12700-12712. https://doi.org/10.1007/s11356-017-8904-x

Anjum, S. A., Ashraf, U., Khan, I., Tanveer, M., Saleem, M. F., \& Wang, L. (2016). Aluminum and chromium toxicity in maize: implications for agronomic attributes, net photosynthesis, physio-biochemical oscillations, and metal accumulation in different plant parts. Water, Air, \& Soil Pollution, 227(9), 326. https://doi.org/ 10.1007/s11270-016-3013-x

Arshad, M., Khan, A. H. A., Hussain, I., Anees, M., Iqbal, M., Soja, G., ... Yousaf, S. (2017). The reduction of chromium (VI) phytotoxicity and phytoavailability to wheat (Triticum aestivum L.) using biochar and bacteria. Applied Soil Ecology, 114, 90-98. https://doi.org/10.1016/j.apsoil.2017.02.021

Ben-Asher, J., Tsuyuki, I., Bravdo, B.-A., \& Sagih, M. (2006). Irrigation of grapevines with saline water: I. Leaf area index, stomatal conductance, transpiration and photosynthesis. Agricultural Water Management, 83(1-2), 13-21. https://doi.org/10.1016/j.agwat.2006.01.002

Bera, A., \& Bokaria, K. (1999). Effect of Tannery Effluent on Seed Germination, Seedling Growth and Chloroplast Pigment Content in Mungbean (Vigna radiata L. Wilczek). Environment and Ecology, 17(4), 958-961.

Blincoe, C., Theisen, M., \& Stoddard-Gilbert, K. (1987). Sample oxidation procedures for the determination of chromium and nickel in biological material. Communications in Soil Science and Plant Analysis, 18(6), 687-697. https://doi.org/10.1080/00103628709367851 
Camargo, F., Okeke, B., Bento, F., \& Frankenberger, W. (2003). In vitro reduction of hexavalent chromium by a cell-free extract of Bacillus sp. ES 29 stimulated by $\mathrm{Cu}^{2+}$. Applied Microbiology and Biotechnology, 62(5-6), 569-573. https://doi.org/10.1007/s00253-003-1291-x

Choppala, G., Bolan, N., Megharaj, M., Chen, Z., \& Naidu, R. (2012). The influence of biochar and black carbon on reduction and bioavailability of chromate in soils. Journal of Environmental Quality, 41(4), 1175-1184. https://doi.org/10.2134/jeq2011.0145

Chrysochoou, M., Zhang, X., \& Amador, J. A. (2013). Aerobic Cr (VI) reduction by bacteria in culture and soil conditions. Soil and Sediment Contamination: An International Journal, 22(3), 273-287. https://doi.org/ $10.1080 / 15320383.2013 .726292$

Corcoran, E. (2010). Sick water? The central role of wastewater management in sustainable development: A rapid response assessment. UNEP/Earthprint.

Dong, X., Ma, L. Q., \& Li, Y. (2011). Characteristics and mechanisms of hexavalent chromium removal by biochar from sugar beet tailing. Journal of Hazardous Materials, 190(1-3), 909-915. https://doi.org/ 10.1016/j.jhazmat.2011.04.008

Emmert, E. (1932). Field method for estimating nitrate, phosphate, and potassium in plants. Plant Physiology, 7(2), 315. https://doi.org/10.1104/pp.7.2.315

EPA. (1974). The Safe Drinking Water Act. Public Law (pp. 93-523). EPA, USA.

Estefan, G., Sommer, R., \& Ryan, J. (2013). Methods of soil, plant, and water analysis. A Manual for the West Asia and North Africa Region, 3.

FAO. (2008). Water and Food Security. FAO Water Reports, 36. FAO, Rome.

Haydar, S., \& Aziz, J. A. (2009). Characterization and treatability studies of tannery wastewater using chemically enhanced primary treatment (CEPT) - A case study of Saddiq Leather Works. Journal of Hazardous Materials, 163(2-3), 1076-1083. https://doi.org/10.1016/j.jhazmat.2008.07.074

Hsu, N.-H., Wang, S.-L., Lin, Y.-C., Sheng, G. D., \& Lee, J.-F. (2009). Reduction of Cr (VI) by crop-residue-derived black carbon. Environmental Science \& Technology, 43(23), 8801-8806. https://doi.org/10.1021/es901872x

Jeffery, S., Verheijen, F. G., van der Velde, M., \& Bastos, A. C. (2011). A quantitative review of the effects of biochar application to soils on crop productivity using meta-analysis. Agriculture, Ecosystems \& Environment, 144(1), 175-187. https://doi.org/10.1016/j.agee.2011.08.015

Jun, R., Ling, T., \& Guanghua, Z. (2009). Effects of chromium on seed germination, root elongation and coleoptile growth in six pulses. International Journal of Environmental Science \& Technology, 6(4), 571-578. https://doi.org/10.1007/BF03326097

Kato, Y., Sun, X., Zhang, L., \& Sakamoto, W. (2012). Cooperative D1 degradation in the photosystem II repair mediated by chloroplastic proteases in Arabidopsis. Plant Physiology, 159(4), 1428-1439. https://doi.org/ 10.1104/pp.112.199042

Kumar, S., Masto, R. E., Ram, L. C., Sarkar, P., George, J., \& Selvi, V. A. (2013). Biochar preparation from Parthenium hysterophorus and its potential use in soil application. Ecological Engineering, 55, 67-72. https://doi.org/10.1016/j.ecoleng.2013.02.011

Laird, D. A., Fleming, P., Davis, D. D., Horton, R., Wang, B., \& Karlen, D. L. (2010). Impact of biochar amendments on the quality of a typical Midwestern agricultural soil. Geoderma, 158(3-4), 443-449. https://doi.org/10.1016/j.geoderma.2010.05.013

Lehmann, J., da Silva Jr., J. P., Rondon, M., Cravo, M. D. S., Greenwood, J., Nehls, T., ... Glaser, B. (2002). Slash-and-char-a feasible alternative for soil fertility management in the central Amazon. Paper presented at the Proceedings of the 17th World Congress of Soil Science.

Liu, T., Wang, Z.-L., Zhao, L., \& Yang, X. (2012). Enhanced chitosan/Fe0-nanoparticles beads for hexavalent chromium removal from wastewater. Chemical Engineering Journal, 189, 196-202. https://doi.org/10.1016/ j.cej.2012.02.056

Liu, Y.-G., Xu, W.-H., Zeng, G.-M., Li, X., \& Gao, H. (2006). Cr (VI) reduction by Bacillus sp. isolated from chromium landfill. Process Biochemistry, 41(9), 1981-1986. https://doi.org/10.1016/j.procbio.2006.04.020 
Lu, H., Zhang, W., Yang, Y., Huang, X., Wang, S., \& Qiu, R. (2012). Relative distribution of Pb2+ sorption mechanisms by sludge-derived biochar. Water Research, 46(3), 854-862. https://doi.org/10.1016/j.watres. 2011.11 .058

Mallick, S., Sinam, G., Mishra, R. K., \& Sinha, S. (2010). Interactive effects of Cr and Fe treatments on plants growth, nutrition and oxidative status in Zea mays L. Ecotoxicology and Environmental Safety, 73(5), 987-995. https://doi.org/10.1016/j.ecoenv.2010.03.004

Masulili, A., Utomo, W. H., \& Syechfani, M. (2010). Rice husk biochar for rice based cropping system in acid soil 1. The characteristics of rice husk biochar and its influence on the properties of acid sulfate soils and rice growth in West Kalimantan, Indonesia. Journal of Agricultural Science, 2(1), 39. https://doi.org/ $10.5539 /$ jas.v2n1p39

Mayak, S., Tirosh, T., \& Glick, B. R. (2004). Plant growth-promoting bacteria confer resistance in tomato plants to salt stress. Plant Physiology and Biochemistry, 42(6), 565-572. https://doi.org/10.1016/j.plaphy. 2004.05.009

Mohan, D., Rajput, S., Singh, V. K., Steele, P. H., \& Pittman Jr., C. U. (2011). Modeling and evaluation of chromium remediation from water using low cost bio-char, a green adsorbent. Journal of Hazardous Materials, 188(1-3), 319-333. https://doi.org/10.1016/j.jhazmat.2011.01.127

Novak, J. M., Lima, I., Xing, B., Gaskin, J. W., Steiner, C., Das, K., ... Busscher, W. J. (2009). Characterization of designer biochar produced at different temperatures and their effects on a loamy sand. Annals of Environmental Science, 3(1), 195-206.

Park, J. H., Choppala, G. K., Bolan, N. S., Chung, J. W., \& Chuasavathi, T. (2011). Biochar reduces the bioavailability and phytotoxicity of heavy metals. Plant and Soil, 348(1-2), 439. https://doi.org/10.1007/ s11104-011-0948-y

Raspor, P., Batič, M., Jamnik, P., Josić, D., Milačič, R., Paš, M., ... Skrt, M. (2000). The influence of chromium compounds on yeast physiology: A review. Acta Microbiologica et Immunologica Hungarica, 47(2-3), 143-173. https://doi.org/10.1556/AMicr.47.2000.2-3.2

Reddy, V. R., \& Behera, B. (2006). Impact of water pollution on rural communities: An economic analysis. Ecological Economics, 58(3), 520-537. https://doi.org/10.1016/j.ecolecon.2005.07.025

Şahin, Y., \& Öztürk, A. (2005). Biosorption of chromium (VI) ions from aqueous solution by the bacterium Bacillus thuringiensis. Process Biochemistry, 40(5), 1895-1901. https://doi.org/10.1016/j.procbio.2004. 07.002

Sánchez, M. E., Lindao, E., Margaleff, D., Martinez, O., \& Moran, A. (2009). Pyrolysis of agricultural residues from rape and sunflowers: Production and characterization of bio-fuels and biochar soil management. $J$ Anal Appl Pyrolysis, 85, 142-144. https://doi.org/10.1016/j.jaap.2008.11.001

Saxena, G., Chandra, R., \& Bharagava, R. N. (2016). Environmental pollution, toxicity profile and treatment approaches for tannery wastewater and its chemical pollutants. Reviews of Environmental Contamination and Toxicology, 240, 31-69. https://doi.org/10.1007/398_2015_5009

Shanker, A. K., Cervantes, C., Loza-Tavera, H., \& Avudainayagam, S. (2005). Chromium toxicity in plants. Environment International, 31(5), 739-753. https://doi.org/10.1016/j.envint.2005.02.003

Shen, Y.-S., Wang, S.-L., Tzou, Y.-M., Yan, Y.-Y., \& Kuan, W.-H. (2012). Removal of hexavalent Cr by coconut coir and derived chars-the effect of surface functionality. Bioresource Technology, 104, $165-172$. https://doi.org/10.1016/j.biortech.2011.10.096

Shen, Z.-G., Li, X.-D., Wang, C.-C., Chen, H.-M., \& Chua, H. (2002). Lead phytoextraction from contaminated soil with high-biomass plant species. Journal of Environmental Quality, 31(6), 1893-1900. https://doi.org/ $10.2134 /$ jeq2002.1893

Singh, B., Singh, B. P., \& Cowie, A. L. (2010). Characterisation and evaluation of biochars for their application as a soil amendment. Soil Research, 48(7), 516-525. https://doi.org/10.1071/SR10058

Soltanpour, P., \& Schwab, A. (1977). A new soil test for simultaneous extraction of macro- and micro-nutrients in alkaline soils. Communications in Soil Science and Plant Analysis, 8(3), 195-207. https://doi.org/10.1080/00103627709366714 
Srivastava, S., \& Thakur, I. S. (2006). Isolation and process parameter optimization of Aspergillus sp.for removal of chromium from tannery effluent. Bioresource Technology, 97(10), 1167-1173. https://doi.org/ 10.1016/j.biortech.2005.05.012

Staniek, H., Kostrzewska-Poczekaj, M., Arndt, M., Szyfter, K., \& Krejpcio, Z. (2010). Genotoxicity assessment of chromium (III) propionate complex in the rat model using the comet assay. Food and Chemical Toxicology, 48(1), 89-92. https://doi.org/10.1016/j.fct.2009.09.020

Syed, M., Saleem, T., Shuja-ur-Rehman, Iqbal, M. A., Javed, F., Khan, M. B. S., \& Sadiq, K. (2010). Effects of leather industry on health and recommendations for improving the situation in Pakistan. Archives of Environmental \& Occupational Health, 65(3), 163-172. https://doi.org/10.1080/19338241003730895

Wang, Q., Qian, H., Yang, Y., Zhang, Z., Naman, C., \& Xu, X. (2010). Reduction of hexavalent chromium by carboxymethyl cellulose-stabilized zero-valent iron nanoparticles. Journal of Contaminant Hydrology, 114(1-4), 35-42. https://doi.org/10.1016/j.jconhyd.2010.02.006

Zhang, M.-K., Liu, Z.-Y., \& Wang, H. (2010). Use of single extraction methods to predict bioavailability of heavy metals in polluted soils to rice. Communications in Soil Science and Plant Analysis, 41(7), 820-831. https://doi.org/10.1080/00103621003592341

Zhang, X., Wang, H., He, L., Lu, K., Sarmah, A., Li, J., ... Huang, H. (2013). Using biochar for remediation of soils contaminated with heavy metals and organic pollutants. Environmental Science and Pollution Research, 20(12), 8472-8483. https://doi.org/10.1007/s11356-013-1659-0

\section{Copyrights}

Copyright for this article is retained by the author(s), with first publication rights granted to the journal.

This is an open-access article distributed under the terms and conditions of the Creative Commons Attribution license (http://creativecommons.org/licenses/by/4.0/). 